and nifedipine will not reduce after-load. Nevertheless, the negative inotropic effect may precipitate pulmonary oedema if the left ventricular end diastolic pressure is raised. Nifedipine should be avoided in the presence of a fixed obstruction to left ventricular ejection and raised ventricular diastolic pressures.

1 Anonymous. Drug treatment of chronic stable angina pectoris. $\mathrm{Br} \mathrm{Med} \mathcal{F}$ $1978 ; \mathrm{i}: 462-3$.

${ }^{2}$ Hashimoko K, Kimura E, Kotayashi T, eds. 1st international Adalat symposium. New therapy of ischaemic heart disease. Tokyo: University of Tokyo Press, 1975.

3 Olivari MT, Bartorelli C, Polese A, Fiorentini C, Moruzzi P, Guazzi M. Treatment of hypertension with nifedipine, a calcium antagonist agent. Circulation 1979;59:1956-62.

4 Polese A, Fiorentini C, Olivari MT, Guazzi M. Clinical use of a calcium antagonistic agent (nifedipine) in acute pulmonary oedema. $A m \mathcal{F} \mathrm{Med}$ $1979 ; 66: 825-30$.

(Accepted 14 March 1980)

Department of Cardiology, Wentworth Hospital, P B Jacobs, Natal 4026, South Africa

DAVID J GILLMER, MRCP, physician and lecturer

PETER KARK, MB, registra

\section{Major and minor salivary gland swelling in Mycoplasma pneumoniae infection}

Mycoplasma pneumoniae is a common respiratory pathogen predominantly associated with pneumonia or an influenza-like illness. ${ }^{1}$ $M$ pneumoniae may also cause a range of disorders including exanthemata $^{2}$ and mucocutaneous lesions, especially erythema multiforme. ${ }^{3}$ Salivary gland swelling, however, has not been reported in association with $M$ pneumoniae infection. We report a case of $M$ pneumoniae infection in which the parotid, submandibular, sublingual, labial, and palatal salivary glands were all affected.

\section{Case report}

A 19-year-old woman was admitted to hospital in July 1979 with a history of a productive cough for 10 days unresponsive to ampicillin and enlargement of her parotid, submandibular, and sublingual salivary glands for two days. She had pulmonary consolidation in the left lower zone but no fever. The labial mucosa was ulcerated and many of the minor glands of both upper and lower lips and the soft palate were enlarged (fig $(a)$ ). There

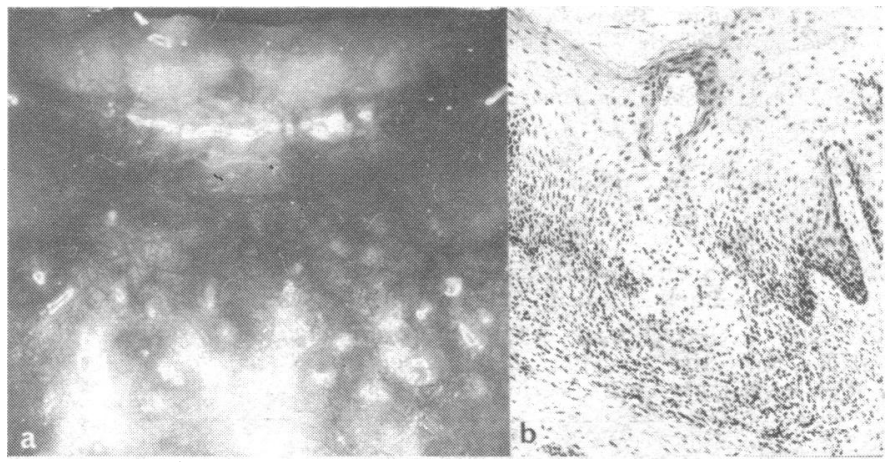

Mycoplasma pneumoniae infection: (a) enlargement of multiple labial mino salivary glands; (b) section of labial salivary gland showing mucus extravasation cyst (stained with haematoxylin and eosin; original magnification $\times 200$ ).

was also bilateral enlargement of all major salivary glands. Her total white cell count was $10 \times 10^{9} / 1\left(10000 / \mathrm{mm}^{3}\right)$ with a normal differential count. The complement-fixing antibody titre to $M$ pneumoniae rose from 1:16 to 1:1024 during her admission. The pneumonia and major salivary gland swellings settled with erythromycin treatment over nine days but she developed erythema nodosum on her thighs and legs. The minor salivary gland swellings persisted for a further two months before resolving. Labial biopsy showed a prominent periductal lymphocytic infiltrate with evidence of damage to the ductal epithelium, and considerable disruption of acinar architecture with mucus spillage into the connective tissue (fig (b)).

\section{Comment}

The nature of the infection in this patient, suggested by the clinical features of persistent cough and erythema nodosum, was confirmed by finding a rise of over fourfold in the serum complement fixation titre to $M$ pneumoniae. The initial low antibody titre indicated that an anamnestic response was unlikely. A most unusual feature was the involvement of multiple salivary glands. The swelling of multiple intraoral (minor) salivary glands is unique and appeared to be due to the escape of salivary mucus from the duct system to form multiple small mucus extravasation cysts, or mucoceles. The swellings of the major salivary glands were clinically indistinguishable from mumps, which may be due to a number of different organisms ${ }^{4}$ but has not been reported in mycoplasma infection. Although mycoplasmas are found in the normal oropharynx they have not been implicated in the more common oral diseases such as recurrent ulceration ${ }^{5}$ or in any salivary gland disorder.

1 Epidemiology. Mycoplasma pneumoniae 1977. Br Med f 1978;i:726.

2 Cherry JD, Hurwitz ES, Welliver RC. Mycoplasma pneumoniae infections and exanthems. $\mathcal{F}$ Pediatr $1975 ; 87: 369-73$.

${ }^{3}$ Lind K. Mucocutaneous reactions during Mycoplasma pneumoniae infection. Lancet 1978; :655.

4 Mason DK, Chisholm DM. Salivary glands in health and disease. London: WB Saunders, 1975

${ }^{5}$ Gordon AM, Dick HM, Mason DK. Manderson WG, Crichton WB. Mycoplasmas and recurrent oral ulceration. F Clin Pathol 1967;20:865-8.

(Accepted 14 March 1980)

University Department of Oral Medicine and Pathology, Glasgow

Dental Hospital and School, Glasgow G2 3JZ

W WRAY, MB, FDS, lecturer

C SCULLY, PHD, FDS, lecture

J RENNIE, PHD, FDS, lecturer

D K MASON, MD, FDS, professor

Department of Infectious Diseases, Belvidere Hospital, Glasgow G31 4PG

W C LOVE, MB, FRCP, honorary clinical lecturer

\section{Hyperglycaemic hyperosmolar non-ketotic diabetic coma presenting as severe dysphagia}

Dysfunction of oesophageal motility and of the lower oesophageal sphincter has been reported in patients with diabetes. ${ }^{12}$ These abnormalities are presumed to be due to autonomic neuropathy and may cause minor symptoms such as heartburn. I have recently seen two patients, previously without gastrointestinal symptoms, whose presenting complaint was severe dysphagia, and both were suffering from non-ketotic diabetic coma.

\section{Case reports}

The first patient was a 58-year-old woman with maturity-onset diabetes of 11 years' duration, known ischaemic heart disease, and dependent ankle oedema. Her treatment was chlorpropamide $375 \mathrm{mg}$ daily with a 150-g carbohydrate diet and oxprenolol $160 \mathrm{mg}$, perhexiline $100 \mathrm{mg}$, and amiloride $5 \mathrm{mg}$-hydrochlorothiazide $50 \mathrm{mg}$ twice daily. For two weeks before admission she complained of progressive dysphagia for solids (she had had no previous gastrointestinal problems) associated with a weight loss of $6 \mathrm{~kg}$. Before her emergency admission, precipitated by drowsiness, she could hardly swallow liquids. On admission she was extremely dehydrated but normotensive. Her blood urea concentration was $105 \mathrm{mmol} / 1(630 \mathrm{mg} / 100 \mathrm{ml})$ and her plasma electrolytes were sodium $108 \mathrm{mmol}(\mathrm{mEq}) / 1$, potassium $5 \cdot 3 \mathrm{mmol}(\mathrm{mEq}) / 1$, chloride $60 \mathrm{mmol}(\mathrm{mEq}) / 1$, bicarbonate $22 \mathrm{mmol}(\mathrm{mEq}) / \mathrm{l}$. Her blood glucose was $64 \mathrm{mmol} / \mathrm{l}(1152 \mathrm{mg} / 100 \mathrm{ml})$ and her urine (Clinitest) contained over $2 \%$ sugar but no ketones. The calculated plasma osmolality ${ }^{3}$ was $385 \mathrm{mmol} / 1$ After treatment with intravenous fluids and insulin her blood urea and 
electrolyte concentrations returned to normal and her diabetes was easily controlled on biphasic insulin (Rapitard) 16 units daily. After recovery the diuretics were stopped but oxprenolol and perhexiline were continued. Her swallowing completely recovered and a barium swallow was normal.

The second patient was a 70-year-old woman with maturity-onset diabetes of 14 years" duration treated with diet alone, but she also took bumetanide $1 \mathrm{mg}$ daily for dependent ankle oedema. After a spell of hot weather she had polyuria for two weeks and had been unable to eat any solid food because of increasing dysphagia. She had lost $5 \mathrm{~kg}$ over seven days. On admission she was extremely dehydrated although normotensive. Her blood urea concentration was $23 \mathrm{mmol} / 1(138 \mathrm{mg} / 100 \mathrm{ml})$ and her plasma electrolyte concentrations were sodium $139 \mathrm{mmol}(\mathrm{mEq}) / \mathrm{l}$, potassium $5 \cdot 1 \mathrm{mmol}(\mathrm{mEq}) / \mathrm{l}$, chloride $90 \mathrm{mmol} / 1(\mathrm{mEq}) / 1$, bicarbonate $27 \mathrm{mmol}(\mathrm{mEq}) / 1$. Her blood glucose concentration was $56.5 \mathrm{mmol} / 1(1017 \mathrm{mg} / 100 \mathrm{ml})$. The urine contained over $2 \%$ glucosuria but no ketones. Her calculated plasma osmolality was 357 $\mathrm{mmol} / \mathrm{l}$. With intravenous fluids and insulin her blood urea and electrolyte concentrations returned to normal. Her diabetes was well controlled on Lente insulin 32 units daily. A barium swallow showed a small hiatus hernia but no cause for her dysphagia, which had completely disappeared.

\section{Comment}

Both patients complained of severe dysphagia at the time they had clinical and biochemical features of hyperglycaemic, hyperosmolar, non-ketotic diabetic coma. Their illness coincided with a period of hot weather when both had been taking diuretics. The association of thiazide and other diuretic treatment with this form of diabetic coma is well recognised, ${ }^{4}$ but severe dysphagia (such that one of the patients was thought to have oesophageal obstruction) has not been reported as a presenting complaint of this condition. The mechanism must presumably be related to a loss of tissue turgor in the oesophageal epithelium related to the dehydration and disturbed biochemical values, since there was no evidence of cranial nerve dysfunction. Dysphagia in elderly diabetics taking diuretics may be a symptom of disturbed biochemistry.

${ }^{1}$ Mandelstram P, Siegel CI, Lieber A, Siegel M. The swallowing disorder in patients with diabetic neuropathy-gastroenteropathy. Gastroenterology $1969 ; 56: 1-12$

2 Stewart IM, Kosking DJ, Preston BJ, Atkinson M. Oesophageal motor changes in diabetes mellitus. Thorax $1976 ; 31: 278-83$.

${ }^{3}$ Edelman IS, Leibman J, O'Meara MP, Birkenfeld LW. Interrelations between serum sodium concentration, serum osmolarity and total exchangeable sodium, total exchangeable potassium and total body water. F Clin Invest $1958 ; 37: 1236-56$

4 Alberti K. Comas in diabetes. Med Series $1975 ; 2: 640-4$.

(Accepted 18 March 1980)

Department of Medicine, Bristol Royal Infirmary, Bristol BS2 8HW B J BURKE, MD, MRCP, senior medical registrar

\section{Psychoneurotic profiles of smokers and non-smokers}

There is still considerable uncertainty about the personality characteristics of smokers. In a study of over 2000 men Eysenck et al found that smokers were more extraverted than non-smokers but did not detect any differences in neuroticism. The results of several other studies have confirmed the finding on extraversion but have been inconsistent on the relationship between neuroticism or "mental health" and smoking. ${ }^{2}$ One reason may be that most of the groups studied were relatively small and selected. We report the results in smokers, ex-smokers, and non-smokers of a self-rating inventory, the
Middlesex Hospital Questionnaire (MHQ), administered to participants in the Northwick Park Heart Study (NPHS). The MHQ was designed to cover the full range of neurotic symptoms and has been validated in psychiatric outpatients. ${ }^{3}$

\section{Participants, methods, and results}

The design of the NPHS, a prospective study of the relation of haemostatic variables to the development of clinical ischaemic heart disease, has been described. ${ }^{4}$ The participants are recruited from several occupational groups in north-west London. Non-smokers are defined as those who have never regularly smoked more than one cigarette a day or one ounce of tobacco a month. Ex-smokers are defined as those who have ceased smoking at least one month before interview. For those who roll their own cigarettes one gram of tobacco is considered equivalent to one cigarette. The MHQ scores range from nil to 16 on each of six subscales-free floating anxiety (FFA) phobic anxiety (PHO), obsessional traits and symptoms (OBS), somatic concomitants of anxiety (SOM), depression (DEP), and hysterical personality traits (HYS)

Over $95 \%$ of questionnaires were completed satisfactorily. Since scores on the PHO, OBS, SOM, and DEP subscales rise and the score on the HYS subscale falls with age the results have been standardised to age 40 . The table shows that MHQ scores for men smokers were higher than for non-smoker on all of the subscales except OBS. Ex-smokers and pipe and cigar smokers tended to score less than current cigarette smokers. The heaviest cigarette smokers had the highest scores on all of the subscales. Similar results were found for 824 women in the NPHS (not shown). The scores on all subscales except HYS were higher in women than men. Since smokers tend to be of lower social class than non-smokers a two-way analysis of variance was performed taking age and class into account. This showed that current smokers still scored significantly higher than non-smokers on the FFA $(p<0.01)$, PHO $(p<0.001)$, SOM $(p<0.001)$, and HYS $(p<0.001)$ subscales.

\section{Comment}

The NPHS is not primarily concerned with cigarette smoking, so that answers to our questionnaire may have been subject to less bias than in Eysenck's study. In addition, the NPHS is based on working populations rather than the quota samples used by Eysenck. Another explanation for the contrast between his results on neuroticism and ours is that the two questionnaires used may measure different aspects of personality. The fairly clear tendency in our data for scores to rise with increasing cigarette consumption is evidence in favour of a true relationship between neuroticism and smoking. The HYS subscale may measure extraversion rather than hysterical personality traits. ${ }^{5}$ If so, our results confirm the general finding of an association between extraversion and cigarette smoking.

${ }^{1}$ Eysenck HJ, Tarrant M, Woolfe M, England L. Smoking and personality. Br Med $\mathcal{F} 1960 ; \mathrm{i}: 1456-60$.

2 Smith GM. Personality and smoking: a review of the empirical literature. In: W A Hunt, ed. Learning mechanisms in smoking. Chicago: Aldine, 1970

${ }^{3}$ Crown S, Crisp AM. A short clinical diagnostic self-rating scale for psychoneurotic patients. The Middlesex Hospital Questionnaire. Br F Psychiatry 1966;112:917-23.

${ }^{4}$ Meade TW, North WRS. Population based distributions of haemostatic variables. Br Med Bull 1977;33:283-8.

${ }^{5}$ Cockett R. A short diagnostic self-rating scale in the pre-adult remand setting. Br $\mathcal{F}$ Psychiatry 1969;115:1141-50.

(Accepted 10 March 1980)

Medical Research Council Epidemiology and Medical Care Unit,

Northwick Park Hospital, Harrow, Middlesex HA1 3UJ

ANDREW P HAINES, MRCP, MRCGP, member of scientific staff

JOHN D IMESON, MA, MSC, computer scientist

$T$ W MEADE, BM, FRCP, director of unit

Smoking habit and $M H Q$ scores in 2018 white men

\begin{tabular}{|c|c|c|c|c|c|c|c|c|c|c|c|c|c|}
\hline \multirow{2}{*}{ Smoking habit } & & & & & & \multirow[b]{2}{*}{ No } & \multirow[b]{2}{*}{ Age } & \multicolumn{6}{|c|}{ Mean $( \pm S D)$ adjusted to age 40} \\
\hline & & & & & & & & FFA & PHO & OBS & SOM & DEP & HYS \\
\hline $\begin{array}{l}\text { Non-smoker } \\
\text { Ex-smoker } \\
\text { Pipe and cigar } \\
\text { Cigarettes/day: }\end{array}$ & $\because$ & $\begin{array}{l}\cdots \\
\cdots\end{array}$ & $\because$ & $\because$ & $\begin{array}{l}\cdots \\
\cdots\end{array}$ & $\begin{array}{l}508 \\
522 \\
183\end{array}$ & $\begin{array}{l}41 \cdot 2 \\
50 \cdot 1 \\
48 \cdot 5\end{array}$ & $\begin{array}{l}3 \cdot 1( \pm 2 \cdot 7) \\
3 \cdot 3( \pm 2 \cdot 8) \\
3 \cdot 0( \pm 2 \cdot 8)\end{array}$ & $\begin{array}{l}2 \cdot 5( \pm 2 \cdot 1) \\
2 \cdot 9( \pm 2 \cdot 2) \\
3 \cdot 1( \pm 2 \cdot 2)\end{array}$ & $\begin{array}{l}6 \cdot 1( \pm 3.3) \\
5.9( \pm 2 \cdot 9) \\
6.0( \pm 3 \cdot 4)\end{array}$ & $\begin{array}{l}2 \cdot 7( \pm 2 \cdot 2) \\
2 \cdot 9( \pm 2 \cdot 6) \\
2 \cdot 8( \pm 2 \cdot 3)\end{array}$ & $\begin{array}{l}2 \cdot 2( \pm 2 \cdot 3) \\
2 \cdot 4( \pm 2 \cdot 4) \\
2 \cdot 1( \pm 2 \cdot 1)\end{array}$ & $\begin{array}{l}3 \cdot 7( \pm 2 \cdot 9) \\
3 \cdot 9( \pm 2 \cdot 8) \\
4 \cdot 2( \pm 2 \cdot 9)\end{array}$ \\
\hline $\begin{array}{l}1-10 \quad \ldots \\
11-20 \quad \ldots \\
21 \text { or over }\end{array}$ & $\begin{array}{l}\cdots \\
\cdots\end{array}$ & $\begin{array}{l}\cdots \\
\cdots\end{array}$ & $\begin{array}{l}\cdots \\
\cdots\end{array}$ & $\begin{array}{l}\cdots \\
\cdots\end{array}$ & $\begin{array}{l}\cdots \\
\cdots\end{array}$ & $\begin{array}{l}219 \\
355 \\
231\end{array}$ & $\begin{array}{l}48 \cdot 2 \\
46 \cdot 5 \\
46 \cdot 5\end{array}$ & $\begin{array}{l}3 \cdot 5( \pm 3 \cdot 2) \\
3 \cdot 4( \pm 3 \cdot 1) \\
4 \cdot 3( \pm 3 \cdot 5)\end{array}$ & $\begin{array}{l}3.5( \pm 2 \cdot 7) \\
3 \cdot 3( \pm 2 \cdot 3) \\
3.8( \pm 2 \cdot 7)\end{array}$ & $\begin{array}{l}6 \cdot 2( \pm 3 \cdot 5) \\
6 \cdot 0( \pm 2 \cdot 8) \\
6 \cdot 4( \pm 3 \cdot 1)\end{array}$ & $\begin{array}{l}3 \cdot 4( \pm 2 \cdot 9) \\
3 \cdot 9( \pm 2 \cdot 7) \\
4 \cdot 3( \pm 3 \cdot 1)\end{array}$ & $\begin{array}{l}2 \cdot 6( \pm 2 \cdot 7) \\
2 \cdot 5( \pm 2 \cdot 4) \\
3 \cdot 2( \pm 2 \cdot 8)\end{array}$ & $\begin{array}{l}4 \cdot 4( \pm 3 \cdot 0) \\
4 \cdot 1( \pm 2 \cdot 9) \\
4 \cdot 8( \pm 3 \cdot 3)\end{array}$ \\
\hline
\end{tabular}

